\section{Lipofuscin- and melanin-related fundus autofluorescence visualize different retinal pigment epithelial alterations in patients with retinitis pigmentosa}

U Kellner ${ }^{1,2}$, S Kellner ${ }^{1,2}$, BHF Weber ${ }^{3}$, B Fiebig ${ }^{3}$, S Weinitz ${ }^{1}$ and $K$ Ruether $^{4}$

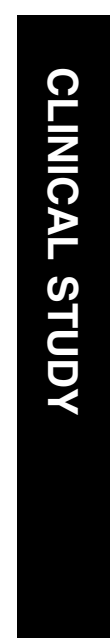

indicate different pathophysiologic processes involving melanin and lipofuscin. Combined NIA and FAF imaging will provide further insight into the pathogenesis of RP and noninvasive monitoring of future therapeutic interventions.

Eye (2009) 23, 1349-1359; doi:10.1038/eye.2008.280; published online 12 September 2008

Keywords: fundus autofluorescence; nearinfrared autofluorescence; retinal pigment epithelium; retinitis pigmentosa

performed with a confocal scanning laser ophthalmoscope (Heidelberg Retina Angiograph 2).

Results Rings of increased FAF were present within an area of preserved retinal pigment epithelium (RPE) at the posterior pole (31/33). Rings of increased NIA were located in the same region as rings of increased FAF. In contrast to FAF, NIA showed a precipitous decline of NIA peripheral to the ring. In larger areas of preserved NIA (11/31), pericentral and foveal NIA were of similar intensity with an area of lower NIA in between. In smaller areas of preserved NIA (20/31), NIA was

homogeneous from the perifovea to the fovea. In one patient without a ring of increased FAF, NIA distribution was normal. In the remaining patient with severely advanced RP, no residual RPE as well as no FAF and NIA were detectable.

Conclusion Characteristic features for FAF and NIA alterations in a heterogeneous group of RP patients indicate a common pathway of RPE degeneration. Patterns of NIA and FAF

\section{Introduction}

Retinitis pigmentosa (RP) comprises a group of disorders characterized by night blindness, progressive visual field loss, subsequent loss of visual acuity and, on ophthalmoscopy, narrowing of retinal vessels, retinal pigment epithelial (RPE) defects, optic disc pallor, and often development of bone spicules. Within the group of RP onset of disease, disease severity and progression as well as clinical findings are highly variable. In addition, RP-like ocular findings develop in several syndromes with additional systemic manifestations. All modes of inheritance have been observed and nonsyndromic as well as syndromic RP has been associated with mutations in multiple genes, which encode proteins with distinct functions in the photoreceptors or the RPE. ${ }^{1}$ The evaluation of the RPE is of major interest as RPE function may directly be affected by a gene mutation or
${ }^{1}$ AugenZentrum Siegburg, Europaplatz 3, Siegburg, Germany

${ }^{2}$ RetinaScience, Postfach 301212, Bonn, Germany

${ }^{3}$ Universität Regensburg, Institut für Humangenetik, Franz-Josef-Strauss Allee 11, Regensburg, Germany

${ }^{4}$ Augenklinik, Charité Campus Rudolf Virchow; Augustenburger Platz 1, Berlin, Germany

Correspondence: U Kellner, Retina Science,

AugenZentrum Siegburg, Europaplatz 3,

53721 Siegburg, Germany Tel: + 491713657433 ;

Fax: + 492284224367

E-mail: kellneru@

mac.com

Received: 13 May 2008 Accepted in revised form: 17 August 2008 Published online: 12 September 2008

This study was presented in part at the ARVO meeting, Fort Lauderdale, 2007, no. 3735

Financial interest/funding: None 
may indirectly react to photoreceptor degeneration. Histological studies have shown that marked alterations of the RPE and the photoreceptors are present in areas with preserved retinal function. ${ }^{2}$ Non-invasive in vivo visualization of RPE alterations could provide a technique to observe the natural course of the disease and to measure the efficacy of future therapeutic intervention. $^{3}$

Recently, autofluorescence techniques have been introduced to monitor two major pigments of the RPE, lipofuscin, and melanin. Lipofuscin accumulates during life in the basal portion of the RPE cells as an endproduct of phagocytotic processes. ${ }^{4,5}$ Increased accumulation of lipofuscin in the RPE has been observed in various degenerative disorders. ${ }^{6-9}$ Lipofuscin distribution can be visualized by fundus autofluorescence (FAF; excitation $488 \mathrm{~nm}$, emission $>500 \mathrm{~nm}) .{ }^{10}$ Characteristic patterns of FAF abnormalities have been reported in $\mathrm{RP}$, and their association with retinal function has been demonstrated. ${ }^{11-14}$ In contrast, melanin is the major protective agent in the RPE cells sheltering the RPE from exposure to light scattering, radiation, oxidative stress, and light damage. 9,15,16 Melanin granules accumulate in the apical part of the RPE cells undergoing a moderate decrease in numbers with age. ${ }^{17}$ Melanin distribution in the RPE can be visualized using near-infrared autofluorescence (NIA, excitation $787 \mathrm{~nm}$, emission $>800 \mathrm{~nm}){ }^{18,19}$ Choroidal melanin is an additional, minor source of NIA. ${ }^{19}$ NIA abnormalities have been reported in age-related macular degeneration, ${ }^{18,19}$ Stargardt disease, ${ }^{20}$ chloroquine retinopathy, ${ }^{21}$ some forms of $\mathrm{RP}_{,}^{22,23}$ and Usher syndrome. ${ }^{24}$

Both imaging methods, FAF and NIA, are non-invasive without any application of dye and can be repeated frequently if necessary. The purpose of this study is to compare NIA and FAF images in patients with RP and to evaluate the usefulness of NIA for diagnostic purposes.

\section{Patients and methods}

A consecutive series of 33 patients from 30 families with non-syndromic or syndromic RP with different modes of inheritance or as simplex cases with no apparent history of familial disease were included in this study. The diagnosis was established in each patient by one author (UK) based on patient and family history, ophthalmoscopy, visual field testing, and full-field or multifocal electroretinography according to the standards of the International Society for Clinical Electrophysiology of Vision. ${ }^{25-29}$ The range of normal FAF and NIA images was evaluated in one eye of 25 healthy subjects aged 12-70 years without ocular disease. These subjects had normal visual acuity for the eye examined and no abnormalities on ophthalmoscopy. All participating patients and study subjects gave informed consent after detailed explanation about the background of the study. The study was performed in adherence to the tenets of the Declaration of Helsinki. We certify that all applicable institutional and governmental regulations concerning the ethical use of human volunteers were followed during this research.

In vivo measurement of FAF and NIA was performed by one author (SW) as described previously. ${ }^{21}$ Images were obtained after medical dilatation of the pupil (phenylephrine $2.5 \%$ and tropicamide $1 \%$, achieving a minimal diameter of $5 \mathrm{~mm}$ ) with a confocal scanning laser ophthalmoscope (Heidelberg Retina Angiograph 2, Heidelberg Engineering, Heidelberg, Germany) using wide-angle or $30^{\circ}$ camera objectives. The image resolution was $768 \times 768$ pixel. The maximum illumination of a $10 \times 10^{\circ}$ field of view was about $2 \mathrm{~mW} / \mathrm{cm}^{2}$. Focusing was achieved using the near-infrared reflectance mode at $815 \mathrm{~nm}$. For FAF, argon laser light $(488 \mathrm{~nm})$ was used to excite lipofuscin autofluorescence. A wide band-pass filter with a cutoff at $500 \mathrm{~nm}$ was inserted in front of the detector. Six pictures per second were recorded and approximately 10 single images were averaged depending on the fixation of the patient.

For NIA, diode laser light $(787 \mathrm{~nm})$ was used to excite melanin autofluorescence. A wide band-pass filter with a cutoff at $800 \mathrm{~nm}$ was inserted in front of the detector. Six pictures per second were recorded and approximately 15 single images were averaged depending on the fixation of the patient.

Normal FAF and NIA images show a dark optic disc and dark vessels due to blocking of autofluorescence (Figure 1). At the posterior pole, FAF and NIA distribution differ remarkably. The lowest FAF intensity is observed in the fovea due to blockage by macular pigment. FAF intensity gradually increases towards the perifoveal region and slightly declines towards the vessel arcades. In contrast, the highest NIA intensity is present at the posterior pole with peak intensity under the fovea. NIA intensity gradually declines towards the perifoveal region. Large choroidal vessels can be visible on some normal NIA images. Using a wide-angle field of view, FAF, and NIA intensity remain unchanged from the mid-periphery towards the periphery (not shown).

FAF and NIA images in RP patients were evaluated on the computer monitor by three examiners (UK, SK, and KR). Abnormalities of FAF and NIA distribution were documented and classified as either increased, normal, reduced, or absent FAF/NIA. The variability of media transmission properties due to the presence or absence of cataract, after cataract or moderate vitreous opacities as well as the associated difficulties of calibration of the FAF/NIA grey scale precluded a quantification of FAF or 

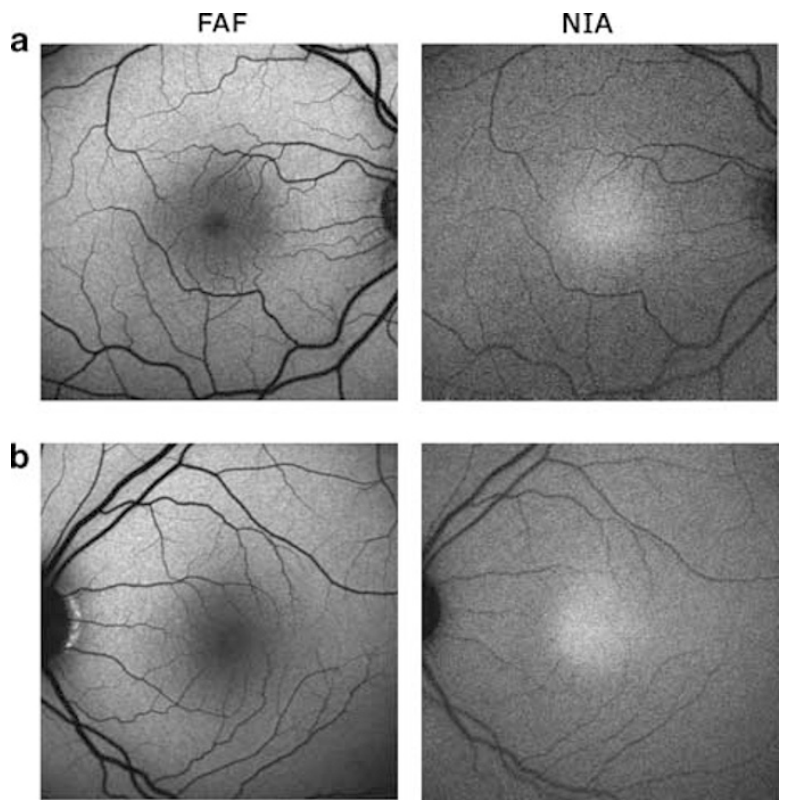

Figure 1 Comparison of normal FAF and NIA distribution. FAF and NIA are blocked by retinal vessels and the optic disc appears dark. (a) FAF shows a foveal decrease and NIA shows a foveal increase in a 15-year-old man. (b) Similar findings in a 46-year-old woman.

NIA intensity in our clinical setting. The horizontal and vertical diameter of FAF and NIA alterations was determined with the measuring tools provided by the software of the Heidelberg retina angiograph. Measurement of characteristic retinal landmarks (eg, vessels and optic disc) in a series of 15 eyes demonstrated no difference between FAF and NIA imaging modes regarding distance measurements.

Genetic testing for syndromic or non-syndromic RP was performed in patients where DNA was available (BHFW and BF; Table 1). The mutational status of nonsyndromic RP was assessed for a single gene or a combination of genes including peripherin-2 (PRPH2), rhodopsin (RHO), retinitis pigmentosa-1 (RP1), centrosomal protein $290 \mathrm{kDa}$ (CEP290), and the X-linked RP GTPase regulator (RPGR). Primer sequences for genomic sequence analysis were designed to cover the coding sequences as well as the immediate $15 \mathrm{bp}$ flanking the respective $5^{\prime}$ and $3^{\prime}$ exon/intron boundaries. Gene mutation testing in syndromic RP was performed by first analysing 430 known variants in eight Usher syndromeassociated genes (CDH23, MYO7A, PCDH15, Harmonin, SANS, Usherin, VLGR1, and USH3A) by the Apex array technology. ${ }^{30}$ These genes carry mutations in patients with various types of Usher syndrome including USH1b, USH1c, USH1d, USH1f, USH1g, USH2a, USH2c, and USH3a. Positive findings with the array hybridizations were subsequently verified by DNA sequencing. All primer sequences and PCR conditions for the sequence analyses are available from one of the authors (BHFW) upon request.

\section{Results}

Detailed clinical and molecular genetic data are summarized for all patients in Table 1. The $33 \mathrm{RP}$ patients included 12 patients with autosomal dominant RP, two patients with autosomal recessive RP, eight patients with simplex RP, six patients with $\mathrm{X}$-linked RP including two manifesting carriers of X-linked RP, four patients with Usher syndrome, and one patient with RP and nephronophthisis. In 7/30 families, disease-associated gene mutations were revealed (RHO, CEP290, MYO7A, PRPH2, and $3 \times$ RPGR; Table 1 ). In two additional unrelated patients (no. 2818 and 2895), mutations in the RP1 gene were detected, although the functional relevance of these mutations to the disease is unknown.

In all patients, findings on ophthalmoscopy, FAF, and NIA did not differ between both eyes except for one patient (no. 2849) with severe trauma on the left eye. In $32 / 33$ patients with RP, preservation of FAF at the posterior pole corresponded to the area of preserved RPE visible on ophthalmoscopy. No residual RPE could be detected by ophthalmoscopy, FAF, or NIA in one patient with progressed X-linked RP at an age of 60 years (no. 2866).

In 29/32 patients with preserved RPE at the posterior pole, within the area of preserved FAF ring-like or more irregular-shaped arcs of increased FAF surrounding the fovea could be distinguished (Figure $2 \mathrm{a}-\mathrm{d}$ ). FAF on both sides of these rings appeared to be similar and within the normal range. Compared to normal probands, subfoveal NIA appeared to be normal in RP patients. In the area of the rings of increased FAF, pericentral NIA was markedly increased to the levels of subfoveal NIA. Beyond this ring of increased NIA, a precipitous decline of NIA intensity towards the periphery was observed. In 11/29 patients with larger areas of preserved NIA, the normal parafoveal decrease of NIA intensity was detectable between the ring of pericentral increased NIA intensity and the normal subfoveal high NIA intensity (Figures $2 a-c$ and $3 a$ ). In 18/29 patients with smaller areas of preserved NIA, the NIA intensity was homogeneous from increased paracentral NIA to normal subfoveal NIA (Figures $2 \mathrm{~d}$ and $3 \mathrm{~b}$ ). Areas of increased NIA did not correspond to ophthalmoscopically increased pigmentation. Visual fields usually showed a concentric narrowing with a residual field that was comparable in diameter to the size of the FAF ring or area of increased NIA (Figure 3).

The horizontal and vertical diameter of the rings of increased FAF and NIA was not significantly different 
Table 1 Patient data

\begin{tabular}{|c|c|c|c|c|c|c|c|}
\hline Patient family & Age & Sex & Gene & History & $V A R E / L E$ & Visual field ${ }^{\mathrm{a}}$ & Full-field $E R G^{\mathrm{b}}$ \\
\hline \multicolumn{8}{|l|}{$a d R P$} \\
\hline $\begin{array}{l}2776 \\
\text { F268, mother of } 2777\end{array}$ & 63 & $\mathrm{~F}$ & Negative: PRPH2 & $\begin{array}{l}\text { NBL, VA loss at } 40 \text { years of } \\
\text { age, amblyopia LE, } \\
\text { additional affected family } \\
\text { members }\end{array}$ & $\begin{array}{l}20 / 125 \\
\mathrm{HM}\end{array}$ & Severe constriction & $\begin{array}{l}\text { Residual } \\
\text { responses }\end{array}$ \\
\hline $\begin{array}{l}2778 \\
\text { F268, son of } 2776\end{array}$ & 24 & M & $\begin{array}{l}\text { Not examined (negative } \\
\text { result of mother) }\end{array}$ & $\begin{array}{l}\text { NBL, VA loss at } 14 \text { years of } \\
\text { age, additional affected } \\
\text { family members }\end{array}$ & $\begin{array}{l}20 / 125 \\
20 / 125\end{array}$ & Severe constriction & $\begin{array}{l}\text { Residual } \\
\text { responses }\end{array}$ \\
\hline $\begin{array}{l}2697 \\
\text { F289, daughter of } \\
2928\end{array}$ & 45 & $\mathrm{~F}$ & $\begin{array}{l}\text { Negative: PRPH2, RHO, } \\
\text { RP1 }\end{array}$ & NBL at 15 years of age & $\begin{array}{l}20 / 50 \\
20 / 32\end{array}$ & Severe constriction & $\begin{array}{l}\text { No recordable } \\
\text { responses }\end{array}$ \\
\hline $\begin{array}{l}2928 \\
\text { F289, father of } 2697\end{array}$ & 84 & M & $\begin{array}{l}\text { Not examined (negative } \\
\text { result of daughter) }\end{array}$ & NBL since youth & $\begin{array}{l}20 / 1000 \\
20 / 200\end{array}$ & Not detectable & $\begin{array}{l}\text { No recordable } \\
\text { responses }\end{array}$ \\
\hline 2645 & 63 & $\mathrm{M}$ & $\begin{array}{l}\text { PRPH2 c.745G }>\text { A } \\
\text { (p.Gly249Ser) }\end{array}$ & $\begin{array}{l}\text { NBL since } 20 \text { years of age, } \\
\text { several affected family } \\
\text { members }\end{array}$ & $\begin{array}{l}20 / 40 \\
20 / 40\end{array}$ & Severe constriction & $\begin{array}{l}\text { Severely } \\
\text { reduced }\end{array}$ \\
\hline 2695 & 60 & $\mathrm{~F}$ & $\begin{array}{l}\text { Negative: PRPH2, RHO, } \\
\text { RP1 }\end{array}$ & $\begin{array}{l}\text { VA loss at } 55 \text { years of age, } \\
\text { affected father }\end{array}$ & $\begin{array}{l}20 / 40 \\
20 / 40\end{array}$ & Severe constriction & $\begin{array}{l}\text { Markedly } \\
\text { reduced, } \\
\text { DA > LA }\end{array}$ \\
\hline $\begin{array}{l}\text { 2818, variable } \\
\text { penetrance within } \\
\text { family }\end{array}$ & 13 & M & $\begin{array}{l}\text { RP1 (variant c.5375C }>\text { G } \\
\text { (p.Ala1792Gly) with } \\
\text { undefined pathogeneity); } \\
\text { negative: PRPH2, RHO }\end{array}$ & $\begin{array}{l}\text { NBL, grandfather affected, } \\
\text { father reduced ERG }\end{array}$ & $\begin{array}{l}20 / 25 \\
20 / 25\end{array}$ & $\begin{array}{l}\text { Moderate } \\
\text { constriction }\end{array}$ & $\begin{array}{l}\text { Unreliable due } \\
\text { to limited } \\
\text { cooperation }\end{array}$ \\
\hline 2819 & 37 & $\mathrm{~F}$ & $\begin{array}{l}\text { Negative: PRPH2, RHO, } \\
\text { RP1 }\end{array}$ & $\begin{array}{l}\text { NBL since } 20 \text { years of age, } \\
\text { mother affected }\end{array}$ & $\begin{array}{l}20 / 32 \\
20 / 20\end{array}$ & $\begin{array}{l}\text { Moderate } \\
\text { constriction }\end{array}$ & $\begin{array}{l}\text { Markedly } \\
\text { reduced, } \\
\text { DA }>\text { LA }\end{array}$ \\
\hline 2865 & 62 & $\mathrm{~F}$ & $\begin{array}{l}\text { RHO, c.1033G }>\text { A } \\
\text { (p.Val345Met) }\end{array}$ & $\begin{array}{l}\text { NBL since } 15 \text { years of age, } \\
\text { several affected family } \\
\text { members }\end{array}$ & $\begin{array}{l}20 / 200 \\
20 / 200\end{array}$ & Severe constriction & $\begin{array}{l}\text { No recordable } \\
\text { responses }\end{array}$ \\
\hline 2914 & 49 & M & $\begin{array}{l}\text { Negative: PRPH2, RHO, } \\
\text { RP1 }\end{array}$ & $\begin{array}{l}\text { VA loss since } 37 \text { years of } \\
\text { age, several affected family } \\
\text { members }\end{array}$ & $\begin{array}{l}20 / 40 \\
20 / 32\end{array}$ & Severe constriction & $\begin{array}{l}\text { Severely } \\
\text { reduced }\end{array}$ \\
\hline 2917 & 65 & $\mathrm{~F}$ & NA & $\begin{array}{l}\text { VF loss noted at } 61 \text { years of } \\
\text { age, father affected }\end{array}$ & $\begin{array}{l}20 / 32 \\
20 / 32\end{array}$ & Severe constriction & $\begin{array}{l}\text { Severely } \\
\text { reduced }\end{array}$ \\
\hline 2929 & 45 & M & $\begin{array}{l}\text { Negative: PRPH2, RHO, } \\
\text { RP1 }\end{array}$ & $\begin{array}{l}\text { Val loss since } 20 \text { years of } \\
\text { age, brothers and father } \\
\text { affected }\end{array}$ & $\begin{array}{l}20 / 20 \\
20 / 20\end{array}$ & $\begin{array}{l}\text { Moderate } \\
\text { constriction }\end{array}$ & $\begin{array}{l}\text { Markedly } \\
\text { reduced, } \\
\text { DA }>\text { LA }\end{array}$ \\
\hline \multicolumn{8}{|l|}{$\operatorname{ar} R P$} \\
\hline 2847, LCA & 15 & $\mathrm{~F}$ & $\begin{array}{l}\text { CEP290: } \\
\text { IVS25 + 1655A > G } \\
\text { (p.Cys998X); c.5674G > T }\end{array}$ & $\begin{array}{l}\text { Nystagmus since } \\
\text { childhood, affected } \\
\text { brother, no signs of Joubert }\end{array}$ & $\begin{array}{l}20 / 100 \\
20 / 100\end{array}$ & Severe constriction & $\begin{array}{l}\text { No recordable } \\
\text { responses }\end{array}$ \\
\hline
\end{tabular}


Table 1 (Continued)

\begin{tabular}{|c|c|c|c|c|c|c|c|}
\hline Patient family & Age & Sex & Gene & History & $V A R E / L E$ & Visual field $^{\mathrm{a}}$ & Full-field $E R G^{\mathrm{b}}$ \\
\hline 2921 & 46 & $\mathrm{~F}$ & NA & $\begin{array}{l}\text { NBL since childhood, } \\
\text { affected brother and sister }\end{array}$ & $\begin{array}{l}20 / 63 \\
20 / 32\end{array}$ & Severe constriction & $\begin{array}{l}\text { No recordable } \\
\text { responses }\end{array}$ \\
\hline \multicolumn{8}{|l|}{$s R P$} \\
\hline 1831 & 54 & $\mathrm{~F}$ & NA & NBL since youth & $\begin{array}{l}20 / 25 \\
20 / 32\end{array}$ & Severe constriction & $\begin{array}{l}\text { No recordable } \\
\text { responses }\end{array}$ \\
\hline 2514 & 64 & $\mathrm{~F}$ & NA & $\begin{array}{l}\text { NBL; VA loss at } 60 \text { years of } \\
\text { age }\end{array}$ & $\begin{array}{l}20 / 50 \\
20 / 50\end{array}$ & Severe constriction & $\begin{array}{l}\text { Residual } \\
\text { responses }\end{array}$ \\
\hline 2779 & 59 & $\mathrm{~F}$ & NA & NBL since 28 years of age & $\begin{array}{l}20 / 20 \\
20 / 40\end{array}$ & $\begin{array}{l}\text { Pericentral ring } \\
\text { sotoma }\end{array}$ & $\begin{array}{l}\text { Severely } \\
\text { reduced, } \\
\text { DA }>\text { LA }\end{array}$ \\
\hline 2800 & 56 & M & NA & NBL since 16 years of age & $\begin{array}{l}20 / 63 \\
20 / 63\end{array}$ & Severe constriction & $\begin{array}{l}\text { No recordable } \\
\text { responses }\end{array}$ \\
\hline 2805 & 43 & M & NA & NBL since 23 years of age & $\begin{array}{l}20 / 32 \\
20 / 25\end{array}$ & Severe constriction & $\begin{array}{l}\text { No recordable } \\
\text { responses }\end{array}$ \\
\hline 2868 & 44 & $\mathrm{~F}$ & NA & NBL since childhood & $\begin{array}{l}20 / 32 \\
20 / 200\end{array}$ & $\begin{array}{l}\text { Unreliable due to } \\
\text { cooperation }\end{array}$ & $\begin{array}{l}\text { No recordable } \\
\text { responses }\end{array}$ \\
\hline 2895 & 60 & M & $\begin{array}{l}\text { RP1 (variant c.1380G >C } \\
\text { (p.Lys460Arg) with } \\
\text { undefined pathogeneity); } \\
\text { negative: PRPH2, RHO }\end{array}$ & $\begin{array}{l}\text { VA problems since } 57 \\
\text { years of age }\end{array}$ & $\begin{array}{l}20 / 40 \\
20 / 63\end{array}$ & $\begin{array}{l}\text { Moderate } \\
\text { constriction }\end{array}$ & $\begin{array}{l}\text { Severely } \\
\text { reduced }\end{array}$ \\
\hline 2932 & 30 & M & NA & $\begin{array}{l}\text { VA problems since } 20 \\
\text { years of age }\end{array}$ & $\begin{array}{l}20 / 32 \\
20 / 40\end{array}$ & Severe constriction & $\begin{array}{l}\text { Severely } \\
\text { reduced } \\
\text { DA }>\text { LA }\end{array}$ \\
\hline \multicolumn{8}{|l|}{$x R P$} \\
\hline $\begin{array}{l}2882 \\
\text { F286, mother of } 2885\end{array}$ & 41 & $\mathrm{~F}$ & $\begin{array}{l}\text { RPGR-ORF15+882delG } \\
\text { (p.Glu879LysfsX209) } \\
\text { Negative: RP2 }\end{array}$ & $\begin{array}{l}\text { Visual field loss since } 35 \\
\text { years of age }\end{array}$ & $\begin{array}{l}20 / 40 \\
20 / 40\end{array}$ & Severe constriction & $\begin{array}{l}\text { Residual } \\
\text { responses }\end{array}$ \\
\hline $\begin{array}{l}2885 \\
\text { F286, son of } 2882\end{array}$ & 5 & M & $\begin{array}{l}\text { RPGR-ORF15 + 882delG } \\
\text { (p.Glu879LysfsX209) }\end{array}$ & Problems in the dark & $\begin{array}{l}20 / 32 \\
20 / 32\end{array}$ & $\begin{array}{l}\text { Midperipheral } \\
\text { sensitivity loss }\end{array}$ & $\begin{array}{l}\text { Unreliable due } \\
\text { to limited } \\
\text { cooperation }\end{array}$ \\
\hline 2788 & 33 & $\mathrm{~F}$ & $\begin{array}{l}\text { RPGR-ORF15: + 483- } \\
\text { 484delGA } \\
\text { (p.Glu802ArgfsX23); } \\
\text { Negative: RP2 }\end{array}$ & $\begin{array}{l}\text { NBL since } 23 \text { years of age; } \\
\text { more severely affected } \\
\text { brother }\end{array}$ & $\begin{array}{l}20 / 32 \\
20 / 32\end{array}$ & Severe constriction & $\begin{array}{l}\text { Severely } \\
\text { reduced } \\
\text { DA }>\text { LA }\end{array}$ \\
\hline 2849 & 66 & $\mathrm{M}$ & Negative: RP2; RPGR & $\begin{array}{l}\text { NBL since childhood, LE } \\
\text { lost due to trauma }\end{array}$ & 20/200NLP & Severe constriction & $\begin{array}{l}\text { No recordable } \\
\text { responses }\end{array}$ \\
\hline 2866 & 60 & M & $\begin{array}{l}\text { RPGR-ORF15: } \\
\text { + 699G > T } \\
\text { (p.Glu818Ter) }\end{array}$ & NBL since childhood & $\begin{array}{l}\mathrm{HM} \\
\mathrm{HM}\end{array}$ & Peripheral residues & $\begin{array}{l}\text { No recordable } \\
\text { responses }\end{array}$ \\
\hline 2880 & 28 & $\mathrm{M}$ & Negative: RP2; RPGR & NBL since childhood & $\begin{array}{l}20 / 32 \\
20 / 25\end{array}$ & Severe constriction & $\begin{array}{l}\text { Markedly } \\
\text { reduced }\end{array}$ \\
\hline
\end{tabular}




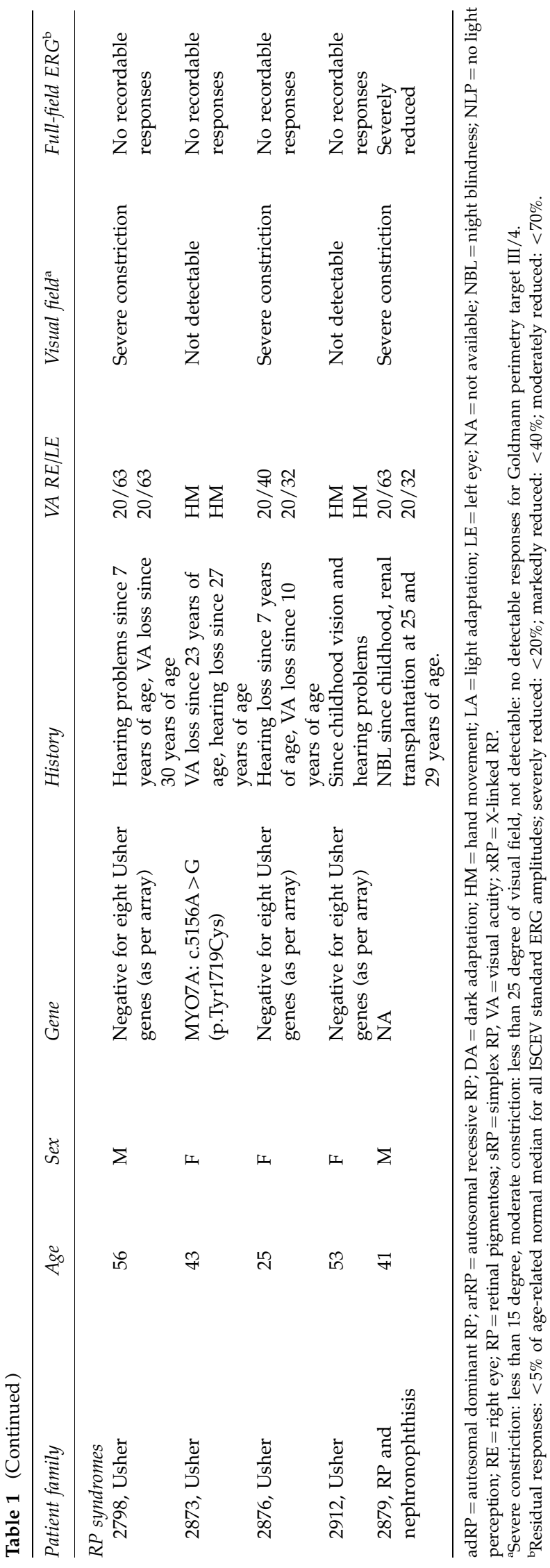

between FAF and NIA (paired $t$-test, $P>0.5$ ). The mean horizontal diameter was larger (FAF and NIA: $3.2 \mathrm{~mm}$; range: $0.65-7.5)$ than the mean vertical diameter (2.51 mm; range: 0.51-7.61) consistent with the usual oval shape of the areas of preserved autofluorescence. The area of pericentral increased NIA had the largest diameter in the youngest patient (no. 2885, 5 years of age, Figure 2a). Although the ring diameter varied with age, all measured diameters decreased with increasing age and more advanced RP (Figures $2 \mathrm{~d}$ and $3 \mathrm{~b}$ ).

In 2/32 patients with preserved RPE (no. 2788 and 2882), a broader ring-like area with swirls of increased FAF surrounded the fovea (Figure 3c). Within the area of these swirls, NIA was homogeneously increased, however, the border of increased NIA was less sharply demarcated compared to the other patients. These patients were both manifesting carriers of X-linked RP.

In contrast to the previous patients, the remaining patient with preserved RPE (no. 2800, Figure 2e) showed a relatively normal distribution of FAF and NIA closely corresponding to an area of preserved RPE at the posterior pole on ophthalmoscopy. No rings of increased FAF were detectable. FAF was slightly lower subfoveal but without the typical decrease seen in normal subjects. In contrast, the area of subfoveal increased NIA was similar to the size seen in normal individuals.

\section{Discussion}

The findings in this study support the presence and different characteristics of two fundus fluorophores in normal and RP-diseased conditions. The difference in the distribution of FAF and NIA abnormalities in the present series of RP patients indicates different pathophysiologic processes involving the fluorophores lipofuscin and melanin. The observed FAF and NIA alterations appear to be a universal phenomenon in RP patients.

The normal distribution of FAF intensity corresponds to the distribution of lipofuscin increasing from the periphery to the posterior pole with a dip at the fovea due to blockade by macula pigment. ${ }^{10,31}$ Accumulation of lipofuscin and correlated increase of autofluorescence depends on the phagocytosis of photoreceptor outer segments. ${ }^{32}$ In various degenerative retinal disorders, increased FAF correlated with lipofuscin accumulation, whereas reduced or absent FAF indicated blockage (eg, retinal vessels), loss of RPE cells, or absence of RPE phagocytosis. ${ }^{26,27,33-40}$ The patterns of FAF distribution in RP patients observed in this study are similar to those reported previously. Ophthalmoscopically preserved areas of RPE at the posterior pole correspond to detectable FAF. Within this area of preserved FAF, a ring of increased FAF that is not discernible by ophthalmoscopy can be detected in the majority of 

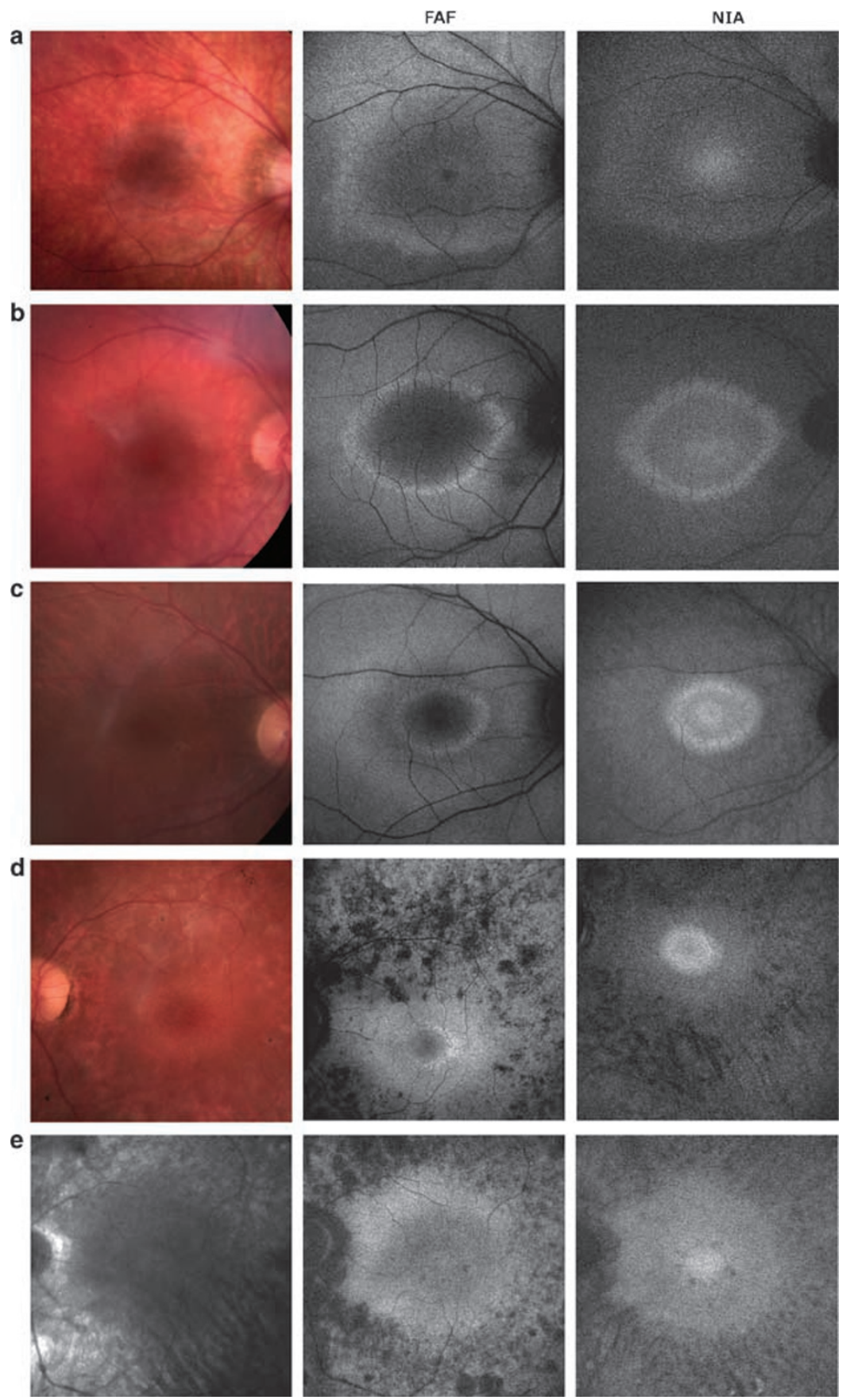

Figure 2 Colour image, FAF and NIA in RP. (a) In the youngest patient (no. 2885, 5 years, xRP), FAF and NIA were increased near the vascular arcades and the optic disc. Both FAF and NIA appeared normal in the fovea. (b) In a patient with adRP (no. 2818, 13 years of age), pericentral NIA was increased within an oval ring of increased FAF with a precipitous decline peripheral to this border. The distribution of NIA intensity within this area was inhomogeneous. (c) A similar finding but a smaller area of preserved NIA was seen in a patient with XRP (no. 2880, 28 years of age). (d) In more progressed arRP, a small ring of increased FAF and an area of homogeneous NIA was present (no. 2921, 46 years of age). (e) In contrast, patient no. 2800 (sRP, 56 years of age) showed a relatively normal distribution of FAF and NIA within the preserved RPE at the posterior pole. FAF was slightly lower subfoveal without marked decrease, and NIA showed a subfoveal increase. Few parafoveal dark spots can be seen on FAF and NIA correspond to RPE loss.

RP patients. ${ }^{41}$ This ring of increased FAF demarcates the area of preserved cone function, ${ }^{11,13,14}$ whereas rod function can be severely affected in areas within the ring. ${ }^{12}$ This is puzzling, as FAF intensity at both sides of the ring of increased FAF appears to be similar, and thus FAF intensity does not correspond to photoreceptor 


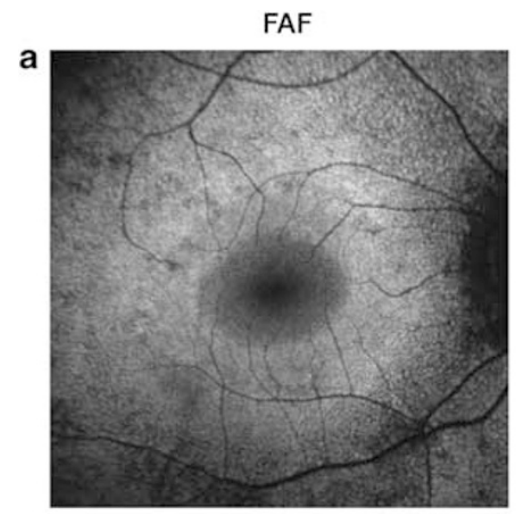

b

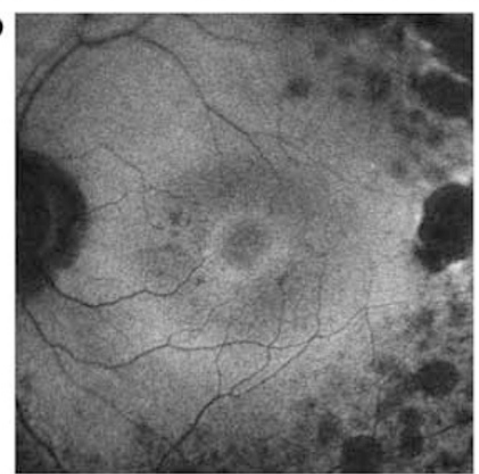

C

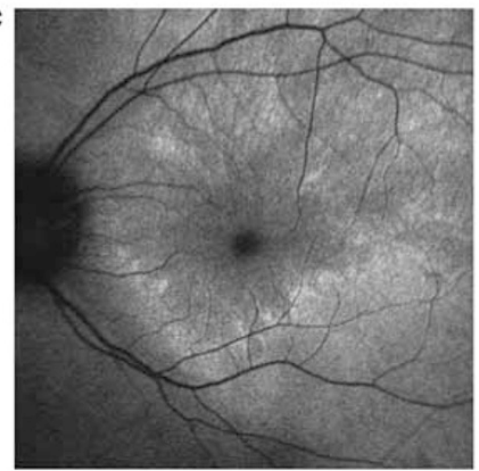

NIA
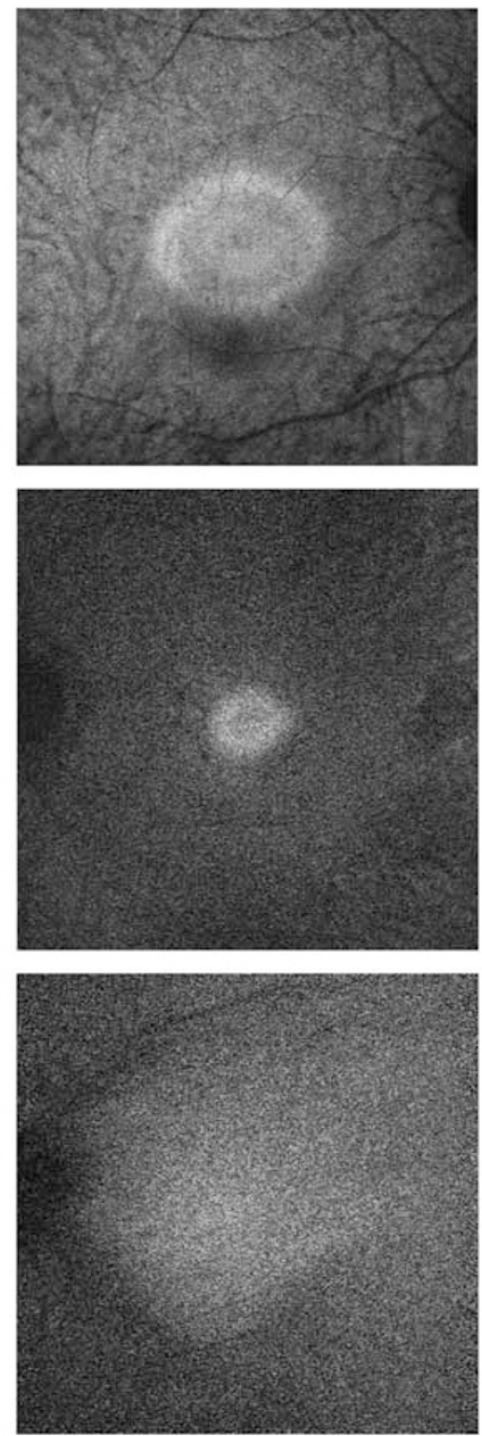

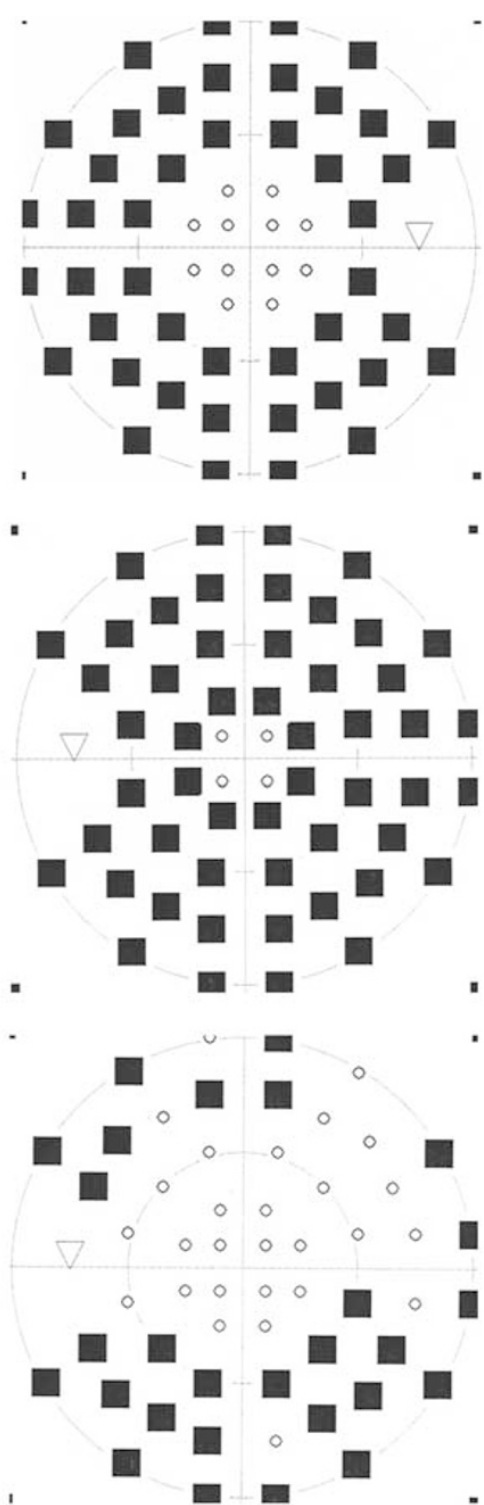

Figure 3 FAF, NIA and visual field in RP. For easier comparison, visual fields are inverted: (a) moderate concentric narrowing corresponding to the area of increased NIA (adRP, no. 2929, 45 years of age), (b) severe concentric narrowing corresponding to the area of increased NIA (arRP, no. 2921, 46 years of age). (c) In a manifesting carrier of xRP (no. 2788, 33 years of age), swirls of increased FAF demarcate an area of homogeneously increased NIA, which shows a less precipitous decline towards the periphery. The preserved visual field corresponds to the area of increased NIA.

function. The swirls of increased FAF in carriers of X-linked RP observed in this study support previous observations. ${ }^{42}$

In this study, rings of increased FAF were associated with rings of perifoveal increased NIA and corresponded closely with a precipitous decline of NIA towards the periphery. Similar NIA alterations have been described in RP associated with CEP290 or RHO gene mutations and in Usher 2A and 3A syndrome. ${ }^{22-24}$ The pericentral increase of NIA in RP is most likely related to the accumulation of melanin or melanin-associated fluorophores. There is consistent evidence based on the distribution of NIA corresponding to RPE melanin distribution, ${ }^{31}$ the contribution of RPE and choroid to NIA and the markedly increased NIA in choroidal nevi that the major contribution to NIA is derived from ocular melanin, although a minor contribution of other fluorophores can not be excluded at present. ${ }^{19}$ Increased NIA corresponds to increased melanin levels (eg, in choroidal nevi), reduced NIA to deficient RPE cells in chloroquine retinopathy, agerelated macular degeneration, or Stargardt disease. ${ }^{18-21}$ 
Three possible mechanisms could explain the altered NIA distribution in RP. First, an increase of melanin, melanolysosomes, or melanolipofuscin content in the RPE cell may occur. Limited melanogenesis has been found in adults, ${ }^{43}$ and as melanin is involved in photoreceptor outer segment phagocytosis, ${ }^{44}$ an increase of melanogenesis as a response to increased phagocytosis of degenerating photoreceptors is feasible. ${ }^{45}$ An increase of melanolysosomes and melanolipofuscin has been documented in degenerative diseases. ${ }^{4,17,46}$ Second, an alternative hypothesis would be an alteration of melanin autofluorescence characteristics that has been observed due to oxidation. ${ }^{47,48}$ Third, a different placement of melanin within the RPE cells could affect NIA. In normal RPE cells, melanin granules accumulate in the apical portion of the cell, whereas lipofuscin is located in the basal portion. ${ }^{17}$ This intracellular distribution may be disturbed in a diseased state. Finally, a combination of the previous three mechanisms may be the basis of the observed NIA alterations.

Histological examinations of RP retinae have focused on melanin in bone spicule formation, and only limited attention was given to alterations of melanin in RPE cells at the posterior pole. ${ }^{49}$ The existing reports support the correlation of NIA findings to RPE melanin distribution in RP. In advanced RP with different forms of inheritance, loss of pure melanin granules and a marked increase of melanolysosomes within the RPE cells has been documented in areas with preserved retinal function corresponding to cones with residual outer segments, and intact cone synaptic pedicles. ${ }^{2,50-52}$ In contrast, RPE cells in the perifovea or near the optic disc underlying cone cell bodies without outer segments, and synaptic pedicles lost their melanin and contained no melanolysosomes. ${ }^{50,53}$ Also, in areas with shortened and disorganized cone and rod outer segments, pyramidshaped RPE protuberances filled with melanin granules were found to surround cone but not rod outer segments. ${ }^{2,51}$ On the basis of these histological findings, we assume that the increased NIA reflects the presence of melanin and melanolysosomes in areas with preserved cone function. The functional findings in our patients and earlier studies on FAF and retinal function ${ }^{11,13,14}$ are in agreement with the histological findings. The area within the rings of increased FAF and NIA are identical with the area of preserved cone function. The larger area of detectable FAF peripheral to the ring of increased FAF most likely indicates preserved RPE cells with loss of viable photoreceptors. This is consistent with OCT findings indicating loss of the outer nuclear layer and corresponding visual field loss in areas peripheral to the perifoveal ring of increased NIA. ${ }^{22,24}$ During disease progression, a reduction of size has been observed for the ring of increased $\mathrm{FAF}^{14}$ and correlates to the decline of the diameter of areas of preserved autofluorescence with age in the present series.

It is impossible to differentiate, whether the increased number of melanolysosomes, the altered oxidation of melanin or the anterior displacement of melanin granules in RPE protuberances contributes predominantly to the increased NIA. Our patient (no. 2866) with nondetectable NIA and missing cone function corresponds to a histological report of the absence of melanin and absence of recent phagocytosis in subfoveal RPE cells losing the monolayer formation in a severe case of RP. ${ }^{54}$

The molecular genetic data in our series are limited, but the detected associated gene mutations and the different modes of inheritance underline the heterogeneity of the RP patients included in this study. On the basis of the presence of similar FAF and NIA alterations in $96.9 \%$ of patients with preserved RPE in the heterogeneous group of RP patients in the present study as well as previously reported RP patients, ${ }^{22-24}$ we hypothesize that the documented pathophysiologic alterations of the RPE are a characteristic phenomenon in $\mathrm{RP}$ patients supporting the concept of a common pathway of RPE degeneration independent of the underlying gene defect.

Although the underlying mechanisms that contribute to NIA alterations need further evaluation, at present, it can be concluded that the combined application of FAF and NIA allows the monitoring of RPE abnormalities and provides insights on different pathophysiologic aspects of the degenerative process in RP. These non-invasive techniques facilitate frequent follow-up examinations, which will be important for future therapeutic trials.

\section{References}

1 Hamel C. Retinitis pigmentosa. Orphanet J Rare Dis 2006; 1: 40.

2 Szamier RB, Berson EL, Klein R, Meyers S. Sex-linked retinitis pigmentosa: ultrastructure of photoreceptors and pigment epithelium. Invest Ophthalmol Vis Sci 1979; 18: 145-160.

3 Maguire AM, Simonelli F, Pierce EA, Pugh Jr EN, Mingozzi $\mathrm{F}$, Bennicelli J et al. Safety and efficacy of gene transfer for Leber's congenital amaurosis. N Engl J Med 2008; 358: 2240-2248.

4 Feeney-Burns L, Hilderbrand ES, Eldridge S. Aging human RPE: morphometric analysis of macular, equatorial, and peripheral cells. Invest Ophthalmol Vis Sci 1984; 25: 195-200.

5 Kennedy CJ, Rakoczy PE, Constable IJ. Lipofuscin of the retinal pigment epithelium: a review. Eye 1995; 9(Part 6): 763-771.

6 Jaffe GJ, Schatz H. Histopathologic features of adult-onset foveomacular pigment epithelial dystrophy. Arch Ophthalmol 1988; 106: 958-960.

7 Steinmetz RL, Garner A, Maguire JI, Bird AC. Histopathology of incipient fundus flavimaculatus. Ophthalmology 1991; 98: 953-956.

8 O'Gorman S, Flaherty WA, Fishman GA, Berson EL. Histopathologic findings in Best's vitelliform macular dystrophy. Arch Ophthalmol 1988; 106: 1261-1268. 
9 Boulton M, Dayhaw-Barker P. The role of the retinal pigment epithelium: topographical variation and ageing changes. Eye 2001; 15: 384-389.

10 Delori FC, Dorey CK, Staurenghi G, Arend O, Goger DG, Weiter JJ. In vivo fluorescence of the ocular fundus exhibits retinal pigment epithelium lipofuscin characteristics. Invest Ophthalmol Vis Sci 1995; 36: 718-729.

11 Robson AG, El-Amir A, Bailey C, Egan CA, Fitzke FW, Webster AR et al. Pattern ERG correlates of abnormal fundus autofluorescence in patients with retinitis pigmentosa and normal visual acuity. Invest Ophthalmol Vis Sci 2003; 44: 3544-3550.

12 Robson AG, Egan CA, Luong VA, Bird AC, Holder GE, Fitzke FW. Comparison of fundus autofluorescence with photopic and scotopic fine-matrix mapping in patients with retinitis pigmentosa and normal visual acuity. Invest Ophthalmol Vis Sci 2004; 45: 4119-4125.

13 Popovic P, Jarc-Vidmar M, Hawlina M. Abnormal fundus autofluorescence in relation to retinal function in patients with retinitis pigmentosa. Graefes Arch Clin Exp Ophthalmol 2005; 243: 1018-1027.

14 Robson AG, Saihan Z, Jenkins SA, Fitzke FW, Bird AC, Webster AR et al. Functional characterisation and serial imaging of abnormal fundus autofluorescence in patients with retinitis pigmentosa and normal visual acuity. $\mathrm{Br} \mathrm{J}$ Ophthalmol 2006; 90: 472-479.

15 Peters S, Lamah T, Kokkinou D, Bartz-Schmidt KU, Schraermeyer U. Melanin protects choroidal blood vessels against light toxicity. Z Naturforsch (C) 2006; 61: 427-433.

16 Wang Z, Dillon J, Gaillard ER. Antioxidant properties of melanin in retinal pigment epithelial cells. Photochem Photobiol 2006; 82: 474-479.

17 Feeney L. Lipofuscin and melanin of human retinal pigment epithelium. Fluorescence, enzyme cytochemical, and ultrastructural studies. Invest Ophthalmol Vis Sci 1978; 17: 583-600.

18 Weinberger AW, Lappas A, Kirschkamp T, Mazinani BA, Huth JK, Mohammadi B et al. Fundus near infrared fluorescence correlates with fundus near infrared reflectance. Invest Ophthalmol Vis Sci 2006; 47: 3098-3108.

19 Keilhauer CN, Delori FC. Near-infrared autofluorescence imaging of the fundus: visualization of ocular melanin. Invest Ophthalmol Vis Sci 2006; 47: 3556-3564.

20 Cideciyan AV, Swider M, Aleman TS, Roman MI, Sumaroka A, Schwartz SB et al. Reduced-illuminance autofluorescence imaging in ABCA4-associated retinal degenerations. J Opt Soc Am A Opt Image Sci Vis 2007; 24: 1457-1467.

21 Kellner U, Kellner S, Weinitz S. Chloroquine retinopathy: lipofuscin- and melanin-related fundus autofluorescence, optical coherence tomography and multifocal electroretinography. Doc Ophthalmol 2008; 116: 119-127.

22 Aleman TS, Cideciyan AV, Sumaroka A, Windsor EA, Herrera W, White DA et al. Retinal laminar architecture in human retinitis pigmentosa caused by rhodopsin gene mutations. Invest Ophthalmol Vis Sci 2008; 49: 1580-1590.

23 Cideciyan AV, Aleman TS, Jacobson SG, Khanna H, Sumaroka A, Aguirre GK et al. Centrosomal-ciliary gene CEP290/NPHP6 mutations result in blindness with unexpected sparing of photoreceptors and visual brain: implications for therapy of Leber congenital amaurosis. Hum Mutat 2007; 28: 1074-1083.

24 Herrera W, Aleman T, Cideciyan AV, Roman AJ, Banin E, Ben-Yosef $\mathrm{T}$ et al. Retinal disease in usher syndrome III caused by mutations in the clarin-1 gene. Invest Ophthalmol Vis Sci 2008; 49: 2651-2660.
25 Kellner U, Renner AB, Tillack H. Fundus autofluorescence and mfERG for early detection of retinal alterations in patients using chloroquine/hydroxychloroquine. Invest Ophthalmol Vis Sci 2006; 47: 3531-3538.

26 Renner AB, Tillack H, Kraus H, Krämer F, Mohr N, Weber $\mathrm{BH}$ et al. Late onset is common in best macular dystrophy associated with VMD2 gene mutations. Ophthalmology 2005; 112: 586-592.

27 Renner AB, Tillack H, Kraus H, Kohl S, Wissinger B, Mohr $\mathrm{N}$ et al. Morphology and functional characteristics in adult vitelliform macular dystrophy. Retina 2004; 24: 929-939.

28 Marmor MF, Holder GE, Seeliger MW, Yamamoto S. Standard for clinical electroretinography (2004 update). Doc Ophthalmol 2004; 108: 107-114.

29 Marmor MF, Hood DC, Keating D, Kondo M, Seeliger MW, Miyake Y. Guidelines for basic multifocal electroretinography (mfERG). Doc Ophthalmol 2003; 106: 105-115.

30 Cremers FP, Kimberling WJ, Kulm M, de Brouwer AP, van Wijk E, te Brinke $\mathrm{H}$ et al. Development of a genotyping microarray for Usher syndrome. J Med Genet 2007; 44: 153-160.

31 Weiter JJ, Delori FC, Wing GL, Fitch KA. Retinal pigment epithelial lipofuscin and melanin and choroidal melanin in human eyes. Invest Ophthalmol Vis Sci 1986; 27: 145-152.

32 Rakoczy P, Kennedy C, Thompson-Wallis D, Mann K, Constable I. Changes in retinal pigment epithelial cell autofluorescence and protein expression associated with phagocytosis of rod outer segments in vitro. Biol Cell 1992; 76: 49-54.

33 Delori FC, Staurenghi G, Arend O, Dorey CK, Goger DG, Weiter JJ. In vivo measurement of lipofuscin in Stargardt's disease-Fundus flavimaculatus. Invest Ophthalmol Vis Sci 1995; 36: 2327-2331.

34 von Ruckmann A, Fitzke FW, Bird AC. Distribution of fundus autofluorescence with a scanning laser ophthalmoscope. Br J Ophthalmol 1995; 79: 407-412.

35 Shiraki K, Kohno T, Moriwaki M, Yanagihara N. Fundus autofluorescence in patients with pseudoxanthoma elasticum. Int Ophthalmol 2001; 24: 243-248.

36 Lois N, Halfyard AS, Bird AC, Holder GE, Fitzke FW. Fundus autofluorescence in Stargardt macular dystrophyfundus flavimaculatus. Am J Ophthalmol 2004; 138: 55-63.

37 Schmitz-Valckenberg S, Bultmann S, Dreyhaupt J, Bindewald A, Holz FG, Rohrschneider K. Fundus autofluorescence and fundus perimetry in the junctional zone of geographic atrophy in patients with age-related macular degeneration. Invest Ophthalmol Vis Sci 2004; 45: $4470-4476$.

38 Lorenz B, Wabbels B, Wegscheider E, Hamel CP, Drexler W, Preising MN. Lack of fundus autofluorescence to 488 nanometers from childhood on in patients with early-onset severe retinal dystrophy associated with mutations in RPE65. Ophthalmology 2004; 111: 1585-1594.

39 Bindewald A, Schmitz-Valckenberg S, Jorzik JJ, Dolar-Szczasny J, Sieber H, Keilhauer C et al. Classification of abnormal fundus autofluorescence patterns in the junctional zone of geographic atrophy in patients with age related macular degeneration. Br J Ophthalmol 2005; 89: 874-878.

40 Wabbels B, Demmler A, Paunescu K, Wegscheider E, Preising MN, Lorenz B. Fundus autofluorescence in children and teenagers with hereditary retinal diseases. Graefes Arch Clin Exp Ophthalmol 2006; 244: 36-45.

41 von Ruckmann A, Fitzke FW, Bird AC. Distribution of pigment epithelium autofluorescence in retinal disease state 
recorded in vivo and its change over time. Graefes Arch Clin Exp Ophthalmol 1999; 237: 1-9.

42 Wegscheider E, Preising MN, Lorenz B. Fundus autofluorescence in carriers of $\mathrm{X}$-linked recessive retinitis pigmentosa associated with mutations in RPGR, and correlation with electrophysiological and psychophysical data. Graefes Arch Clin Exp Ophthalmol 2004; 242: 501-511.

43 Smith-Thomas L, Richardson P, Thody AJ, Graham A, Palmer I, Flemming L et al. Human ocular melanocytes and retinal pigment epithelial cells differ in their melanogenic properties in vivo and in vitro. Curr Eye Res 1996; 15: 1079-1091.

44 Schraermeyer U, Peters S, Thumann G, Kociok N, Heimann $\mathrm{K}$. Melanin granules of retinal pigment epithelium are connected with the lysosomal degradation pathway. Exp Eye Res 1999; 68: 237-245.

45 Peters S, Kayatz P, Heimann K, Schraermeyer U. Subretinal injection of rod outer segments leads to an increase in the number of early-stage melanosomes in retinal pigment epithelial cells. Ophthalmic Res 2000; 32: 52-56.

46 Buchanan TA, Gardiner TA, Archer DB. An ultrastructural study of retinal photoreceptor degeneration associated with bronchial carcinoma. Am J Ophthalmol 1984; 97: 277-287.
47 Kayatz P, Thumann G, Luther TT, Jordan JF, Bartz-Schmidt $\mathrm{KU}$, Esser PJ et al. Oxidation causes melanin fluorescence. Invest Ophthalmol Vis Sci 2001; 42: 241-246.

48 Sarna T, Burke JM, Korytowski W, Rózanowska M, Skumatz $\mathrm{CM}$, Zareba A et al. Loss of melanin from human RPE with aging: possible role of melanin photooxidation. Exp Eye Res 2003; 76: 89-98.

49 Milam AH, Li ZY, Fariss RN. Histopathology of the human retina in retinitis pigmentosa. Prog Retin Eye Res 1998; 17: 175-205.

50 Szamier RB, Berson EL. Retinal ultrastructure in advanced retinitis pigmentosa. Invest Ophthalmol Vis Sci 1977; 16: 947-962.

51 Bunt-Milam AH, Kalina RE, Pagon RA. Clinicalultrastructural study of a retinal dystrophy. Invest Ophthalmol Vis Sci 1983; 24: 458-469.

52 Szamier RB, Berson EL. Retinal histopathology of a carrier of $\mathrm{X}$-chromosome-linked retinitis pigmentosa. Ophthalmology 1985; 92: 271-278.

53 Milam AH, Jacobson SG. Photoreceptor rosettes with blue cone opsin immunoreactivity in retinitis pigmentosa Ophthalmology 1990; 97: 1620-1631.

$54 \mathrm{Kolb} \mathrm{H}$, Gouras P. Electron microscopic observations of human retinitis pigmentosa, dominantly inherited. Invest Ophthalmol 1974; 13: 487-498. 